\title{
Air Pollution by Hydrothermal Volcanism and Human Pulmonary Function
}

\author{
Diana Linhares, ${ }^{1,2}$ Patrícia Ventura Garcia, ${ }^{1,3}$ Fátima Viveiros, ${ }^{2,4}$ \\ Teresa Ferreira, ${ }^{2,4}$ and Armindo dos Santos Rodrigues ${ }^{1,2}$ \\ ${ }^{1}$ Department of Biology, University of the Azores, Ponta Delgada, 9501-801 Azores, Portugal \\ ${ }^{2}$ CVARG, Center for Volcanology and Geological Risks Assessment (CVARG), University of the Azores, Ponta Delgada, \\ 9501-801 Azores, Portugal \\ ${ }^{3}$ CE3C, Centre for Ecology, Evolution and Environmental Changes (CE3C) and Azorean Biodiversity Group, \\ University of the Azores, 9501-801 Ponta Delgada, Portugal \\ ${ }^{4}$ Department of Geosciences, University of the Azores, Ponta Delgada, 9501-801 Azores, Portugal
}

Correspondence should be addressed to Diana Linhares; dlinhares@uac.pt

Received 21 November 2014; Accepted 13 March 2015

Academic Editor: Petros Gikas

Copyright (C) 2015 Diana Linhares et al. This is an open access article distributed under the Creative Commons Attribution License, which permits unrestricted use, distribution, and reproduction in any medium, provided the original work is properly cited.

\begin{abstract}
The aim of this study was to assess whether chronic exposure to volcanogenic air pollution by hydrothermal soil diffuse degassing is associated with respiratory defects in humans. This study was carried in the archipelago of the Azores, an area with active volcanism located in the Atlantic Ocean where Eurasian, African, and American lithospheric plates meet. A cross-sectional study was performed on a study group of 146 individuals inhabiting an area where volcanic activity is marked by active fumarolic fields and soil degassing (hydrothermal area) and a reference group of 359 individuals inhabiting an area without these secondary manifestations of volcanism (nonhydrothermal area). Odds ratio (OR) and 95\% confidence intervals (CIs) were adjusted for age, gender, fatigue, asthma, and smoking. The OR for restrictive defects and for exacerbation of obstructive defects (COPD) in the hydrothermal area was 4.4 (95\% CI 1.78-10.69) and 3.2 (95\% CI 1.82-5.58), respectively. Increased prevalence of restrictions and all COPD severity ranks (mild, moderate, and severe) was observed in the population from the hydrothermal area. These findings may assist health officials in advising and keeping up with these populations to prevent and minimize the risk of respiratory diseases.
\end{abstract}

\section{Introduction}

About $10 \%$ of the worldwide population inhabits or lives in the vicinity of some active or historically active volcano [1]. Despite the hazards associated with volcanic activities, the richness of soils in nutrients attracts people to live in these areas. Several studies have established an association between acute $[2-4]$ and long-term $[5,6]$ exposure to anthropogenic air pollutants and lung function, while only few have analyzed the respiratory effects from volcanogenic air pollution [7-9].

The Azores archipelago (Portugal) comprises nine volcanic inhabited islands, located between $36^{\circ} 45^{\prime}-39^{\circ} 45^{\prime} \mathrm{N}$ and $24^{\circ} 45^{\prime}-31^{\circ} 17^{\prime} \mathrm{W}$ (Figure 1(a)), where the Eurasian, African, and American lithospheric plates meet [10]. On account of this complex tectonic setting, seismic and volcanic activities are frequent in the archipelago [11]. São Miguel Island, the largest of the archipelago, is formed by three major active central volcanoes (Sete Cidades, Fogo, and Furnas), linked by rift zones [12] (Figure 1(b)). Furnas Volcano is located in the eastern part of the island, where present-day volcanic activity is marked by several hydrothermal manifestations consisting of active fumarolic fields, thermal and cold $\mathrm{CO}_{2}$-rich springs, and soil diffuse degassing areas [11,13]. Gases released in these diffuse degassing areas are essentially carbon dioxide $\left(\mathrm{CO}_{2}\right)$ and radon $\left({ }^{222} \mathrm{Rn}\right)$, this last one a radioactive gas. Carbon dioxide is one of the most abundant volcanic gases and is amongst the most important diffused gases released by soil degassing in Furnas Volcano (hydrothermal soil $\mathrm{CO}_{2}$ emissions in Furnas Volcano are estimated to be approximately $968 \mathrm{t} / \mathrm{d}$ ) [14]; this gas, if present at high concentrations, can become particularly dangerous for public health, since it works as asphyxiant preventing 


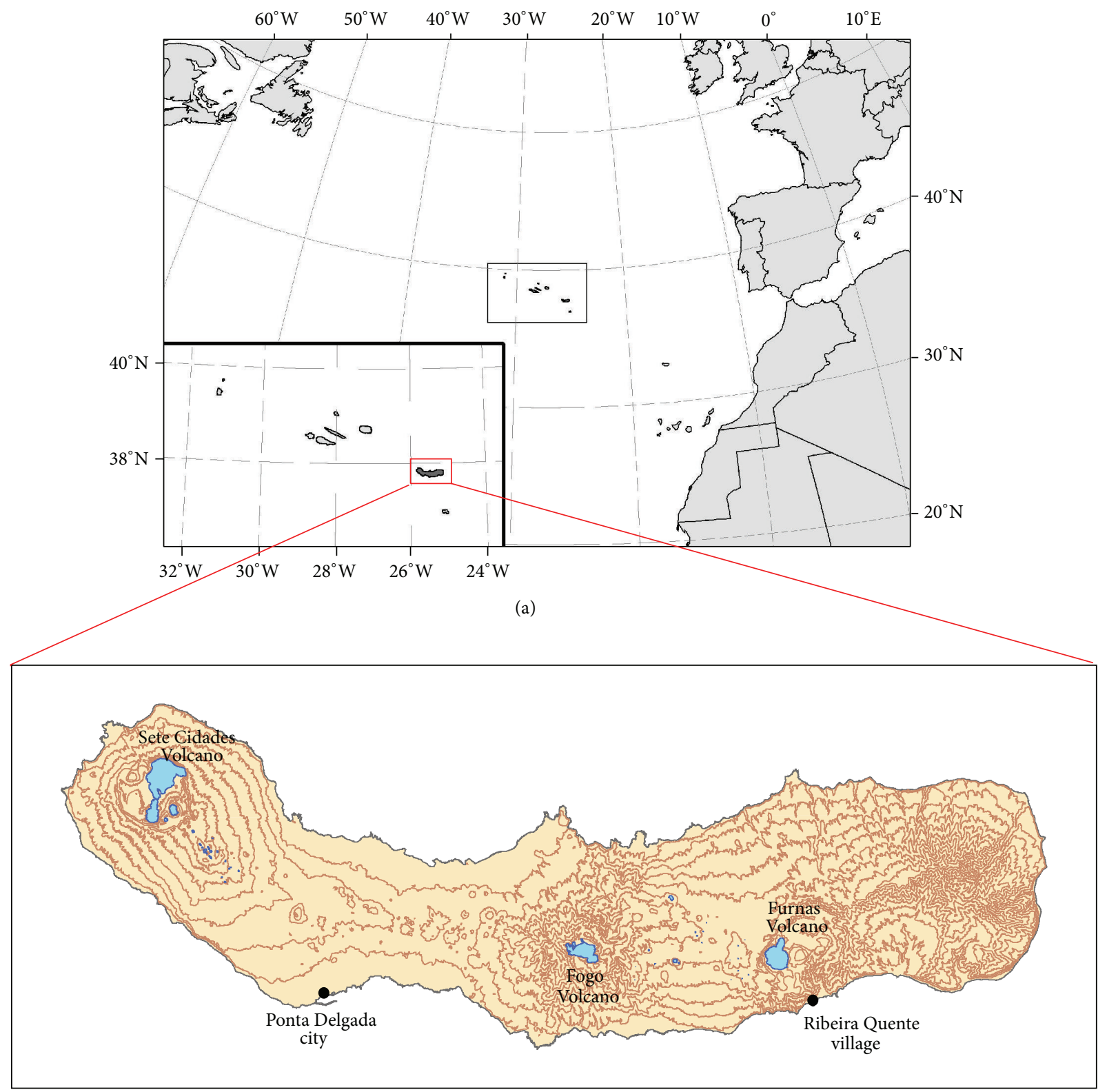

(b)

Figure 1: (a) Location map of the Azores archipelago and (b) São Miguel Island. The places represented on the map correspond to the two studied areas (Ponta Delgada and Ribeira Quente).

oxygen respiration [15]. Previous studies [13] showed that $\mathrm{CO}_{2}$ is released permanently to the atmosphere from soils in volcanic areas not only during eruptive periods, but also during quiescent periods of activity. Considering that $\mathrm{CO}_{2}$ released by soils may enter the buildings through pipes, cracks in the floor, and/or the contact between floor and walls, it is considered important to assess the $\mathrm{CO}_{2}$ flux in buildings. Carbon dioxide level is usually greater inside a building than outside, and it can act as an indicator of ventilation efficiency, showing whether the supply of outside air is sufficient to dilute indoor air contaminants [16]. According to WHO [17], indoor air pollution is responsible for $2.7 \%$ of the diseases worldwide; such effects of indoor air pollution are particularly highlighted in studies regarding the occupational exposure, as it was shown in the review made by Balmes et al. [18] that estimated that $15 \%$ of COPD was attributable to the air quality at the workplace.

Furnas and Ribeira Quente are two villages located, respectively, inside the caldera and in the south flank of Furnas active volcano, where the ground gas emissions that characterize the diffuse degassing areas occur permanently and, thus, inhabitants of such areas are often exposed to elevated concentrations of $\mathrm{CO}_{2}$ from volcanic origin [14]. Previous studies evidenced that Furnas inhabitants have 
TABLE 1: Description of the study populations (study and reference groups) (mean \pm SE for continuous variables or $n$ (\%) for categorical variables).

\begin{tabular}{|c|c|c|c|c|}
\hline & & $\begin{array}{c}\text { Reference group } \\
\text { (Ponta Delgada, } n=359 \text { ) }\end{array}$ & $\begin{array}{c}\text { Study group } \\
\text { (Ribeira Quente, } n=146 \text { ) }\end{array}$ & $P$ value $^{\mathrm{a}}$ \\
\hline \multicolumn{5}{|c|}{ General characteristics } \\
\hline Age (years) & $41.3 \pm 12.7$ & $39.8 \pm 11.2$ & $45.1 \pm 15.3$ & 0.001 \\
\hline Age, $>41^{b}$ & $234(46.3)$ & $152(42.3)$ & $82(56.1)$ & 0.005 \\
\hline Gender, male & $207(40.9)$ & $155(43.1)$ & $52(35.6)$ & 0.117 \\
\hline BMI $\left(\mathrm{kg} / \mathrm{m}^{2}\right)$ & $26.1 \pm 4.4$ & $25.7 \pm 3.9$ & $27.1 \pm 5.4$ & 0.006 \\
\hline $\mathrm{BMI},>26^{\mathrm{c}}$ & $213(42.2)$ & $141(39.3)$ & $72(49.3)$ & 0.041 \\
\hline \multicolumn{5}{|l|}{ Smoking status } \\
\hline Smoker & $163(32.2)$ & $135(37.6)$ & $28(19.1)$ & $<0.001$ \\
\hline Previous smoker & $91(18)$ & $69(19.2)$ & $22(15)$ & 0.271 \\
\hline Easy fatigue, yes & $116(23)$ & $40(11.1)$ & $76(52)$ & $<0.001$ \\
\hline Asthma, yes & $43(8.5)$ & $29(8)$ & $14(9.6)$ & 0.581 \\
\hline \multicolumn{5}{|l|}{ Occupation } \\
\hline White collar & $135(26.7)$ & $122(34)$ & $13(8.9)$ & $<0.001$ \\
\hline Blue collar & $256(50.7)$ & $233(65)$ & $23(15.8)$ & $<0.001$ \\
\hline Other & $114(22.6)$ & $4(1)$ & $110(75.3)$ & $<0.001$ \\
\hline \multicolumn{5}{|l|}{ Study } \\
\hline $\mathrm{FEV}_{1}$ predicted $^{\mathrm{d}}$ & $88.5 \pm 20.4$ & $92.5 \pm 16.6$ & $78.6 \pm 25.2$ & 0.001 \\
\hline FVC predicted & $96.6 \pm 19.2$ & $98.8 \pm 15$ & $91.1 \pm 26.2$ & $<0.001$ \\
\hline $\mathrm{FEV}_{1} / \mathrm{FVC}$ predicted & $91.8 \pm 14.2$ & $93.8 \pm 11.7$ & $87 \pm 18.1$ & $<0.001$ \\
\hline \multicolumn{5}{|l|}{ Lung function } \\
\hline Restriction, yes & $26(5.1)$ & $11(3)$ & $15(10.2)$ & 0.001 \\
\hline COPD, yes & $92(18.2)$ & $43(11.9)$ & $49(33.6)$ & $<0.001$ \\
\hline $\mathrm{CO}_{2}$ flux, $\mathrm{g} / \mathrm{m}^{2} / \mathrm{d}^{\mathrm{e}}$ & & 15.36 & 508 & $<0.001$ \\
\hline
\end{tabular}

${ }^{a} P$ value comparing reference and study groups, by Mann-Whitney for continuous variables and by $\chi^{2}$ for categorical variables.

${ }^{\mathrm{b}} \mathrm{Cut}$-off defined according to the mean value (i.e., 41.3 years) of the observed age distribution in the whole population.

${ }^{c}$ Cut-off defined according to the mean value (i.e., 26.1 BMI) of the observed BMI distribution in the whole population.

${ }^{\mathrm{d}}$ Predicted values from the National Health and Nutrition Examination Survey Cohort.

${ }^{\mathrm{e}} \mathrm{CO}_{2}$ flux is expressed in mean.

a high incidence of chronic bronchitis and of some cancer types (e.g., lip, oral cavity, and pharynx) $[19,20]$ and a higher risk of DNA damage in human buccal epithelial cells [21]. Moreover, a very recent study by Camarinho et al. [22] showed that chronic exposure to volcanogenic air pollutants causes lung injury in wild mice. However, to our knowledge, up to date no study was carried out to assess the association between volcanogenic air pollution by soil diffuse degassing (DDS) and the risk of development of respiratory defects. Therefore, the present study was carried out to evaluate whether chronic exposure to permanent volcanogenic air pollution is a risk factor for human restrictive and obstructive (COPD) respiratory defects.

\section{Methods}

2.1. Study Population. To perform this study, two areas were selected: an area with no secondary manifestations of volcanism, therefore a nonhydrothermal area (Ponta Delgada), and an area where volcanic activity is marked by active fumarolic fields and degassing soils (hydrothermal area) (Ribeira
Quente). A diagnosis campaign was established for evaluation of pulmonary function by spirometry tests for the inhabitants of both areas. Spirometry tests were carried out in either the participants' workplaces or their homes. A standard questionnaire was applied to each individual that volunteered to participate. Medical history data for respiratory symptoms were taken using a standard questionnaire modified from a standardized respiratory symptom questionnaire from American Thoracic Society (ATS) [23] and British Medical Research Council's Committee [24]. Each person was interviewed about their age, height, weight, education, occupation, smoking habits (smoking of cigarettes and/or use of smokeless tobacco), amount of cigarettes smoked/day, fatigue, and general respiratory health status, where asthma was defined by a positive response to "Did any doctor diagnose you with asthma?".

The study group consisted of 146 participants (94 women and 52 men), residents in Ribeira Quente village (Table 1). Ribeira Quente village has 767 inhabitants [25]: 148 children and 619 adults (298 women and 321 men); therefore, the participation rate was $26.3 \%$. This village is located on the south 
flank of Furnas Volcano (São Miguel Island) (Figure 1(b)), in an important diffuse degassing structure (DDS); about $98 \%$ of buildings in this village are placed above anomalous soil $\mathrm{CO}_{2}$ degassing with volcanic-hydrothermal origin $[14,26]$. In addition, several fumaroles may be found along Ribeira Quente stream and dispersed in the village [13]. Thus, Ribeira Quente inhabitants are chronically exposed to gases of volcanic origin, particularly from soil diffuse degassing. Even if no indoor measurements were performed concomitantly to the diagnosis tests, previous works showed that in the diffuse degassing structures indoor $\mathrm{CO}_{2}$ is anomalously high and can reach lethal values during extreme weather events [13]. Permanent release of gases from the soils increases the indoor $\mathrm{CO}_{2}$ concentrations independently of the anthropogenic contribution.

The reference group comprised 359 individuals (204 women and 155 men) working in downtown of Ponta Delgada city (Table 1). Ponta Delgada's downtown has 7818 adult workers [25]; therefore, the participation rate was $4.5 \%$. Ponta Delgada is located in the south side of São Miguel Island (Azores, Portugal; Figure 1(b)), in the Região dos Picos Volcanic Complex, a basaltic rift zone located between Sete Cidades and Fogo Volcanoes, where no manifestations of volcanism have been identified [11].

The Ethics Board of Divino Espirito Santo Hospital (Ponta Delgada, Azores, Portugal) approved the study. All individuals signed a written informed consent, in compliance with the Helsinki Declaration and Oviedo Convention, to participate in this study. Table 1 summarizes the demographic characteristics and main lifestyle habits of the studied populations. Only individuals resident for more than five years in each locality were considered in this study.

2.2. Spirometry Tests. The forced expiratory volume in one second $\left(\mathrm{FEV}_{1}\right)$ and the forced vital capacity (FVC) values were obtained by spirometry in all participants. Spirometry tests were conducted with the participants in an up position wearing a nose clip and a disposable mouth piece using the EasyOne automated portable spirometer (ndd, Zürich, Switzerland), which meets ATS/ERS spirometry standards [27] and is equipped with software that checks for unacceptable maneuvers and compares the measured values with reference tables. Standardized operating procedures were implemented and controlled. Participants performed three to five attempts to provide at least three technically acceptable maneuvers, following the criteria recommended by the ATS [28] and the guidelines of the European Respiratory Society [27]. Postbronchodilator tests were not applied.

Spirometry data were classified categorically as being consistent with either a normal pulmonary function, a restrictive defect, or an obstructive defect. Spirometric detection of restriction was considered in all subjects with normal $\mathrm{FEV}_{1}$ / FVC, with $\mathrm{FVC}<80 \%$ predicted, and $\mathrm{FEV}_{1} / \mathrm{FVC}<70 \%$ was used as a fixed cut-point for obstruction (COPD), according to the third United States National Health and Nutrition Examination Survey (NHANES III) for adult Caucasians. According to the GOLD guidelines, COPD was further classified in the following ranks given by the spirometer output: mild ( $\left.\mathrm{FEV}_{1} \geq 80 \%\right)$, moderate $\left(\mathrm{FEV}_{1}\right.$ 50-79\%), and severe $\left(\mathrm{FEV}_{1} 30-49 \%\right)$.

2.3. Exposure Assessment to Volcanogenic Air Pollution by $D D S$. Carbon dioxide degassing maps may be useful for volcanic/seismic monitoring purposes as they represent a reference for future variations on the state of activity of the volcano [14].

Measurements of soil $\mathrm{CO}_{2}$ released by soil degassing in Ribeira Quente village were carried out recently by Viveiros et al. $[14,26]$. The surveys were made using portable instruments that perform measurements based on the accumulation chamber method [29]. Almost all buildings (about 98\%) in Ribeira Quente village are placed in an anomalous high $\mathrm{CO}_{2}$ degassing zone (DDS), with soil $\mathrm{CO}_{2}$ fluxes that can reach values higher than $25000 \mathrm{~g} / \mathrm{m}^{2} / \mathrm{d}$ [14]. Considering that $\mathrm{CO}_{2}$ released by soils may enter the buildings (e.g., through pipes, cracks in the floor, and/or the contact between floor and walls), $\mathrm{CO}_{2}$ degassing maps produced for Ribeira Quente village $[14,26]$ were used to attribute a $\mathrm{CO}_{2}$ flux value to each building. Even if no indoor measurements were performed, the $\mathrm{CO}_{2}$ released from soils is positively correlated with the indoor $\mathrm{CO}_{2}$ concentrations [13], so measurements applied outside the buildings are indirectly representative of the $\mathrm{CO}_{2}$ concentrations that can be found indoors [13]. Sporadic soil $\mathrm{CO}_{2}$ flux measurements were performed at Ponta Delgada in the areas surrounding the buildings occupied by individuals from the reference group. The 68 measurements performed showed that $\mathrm{CO}_{2}$ flux values were lower than $25 \mathrm{~g} / \mathrm{m}^{2} / \mathrm{d}$ and thus representative of biogenic origin and without hydrothermal contribution.

2.4. Statistical Analysis. Pearson Chi-Square test was used to compare restrictions and COPD prevalence between individuals inhabiting the environment with volcanic degassing and individuals from the reference group. To estimate the association between chronic exposure to an environment with volcanic air pollution and restrictive and obstructive defects (no versus yes), odds ratio (OR) and 95\% confidence intervals (95\% CIs) were calculated using a binary logistic regression model, adjusting for age, gender (male versus female), fatigue (yes versus no), and smoking status (yes versus no).

To estimate the association between chronic exposure to an environment with volcanic air pollution and the increase in the severity COPD, odds ratio (OR) and 95\% confidence intervals (95\% CIs) were calculated using an ordinal logistic regression model, adjusting for age, fatigue (yes versus no), asthma (yes versus no), and smoking status (yes versus no). The occurrence of obstructions was graded on scales, according to their occurrence and severity: 1: without obstruction, and 2 to 4 : with obstruction, from the least severe (2) to the most severe (4).

Mann-Whitney $U$ test was used to compare soil $\mathrm{CO}_{2}$ fluxes released by diffuse degassing between the reference and the study group.

All statistical analysis was performed using IBM SPSS Statistics 20.0 for Windows [30], and the level of statistical significance was set at $P \leq 0.05$. 
TABLE 2: Adjusted association between characteristics of study participants, exposure to volcanogenic soil diffuse degassing (DDS), and restrictive lung defects.

\begin{tabular}{|c|c|c|c|}
\hline Binomial logistic regression & & & $\begin{array}{l}\text { Number of obs. } 505 \\
\text { LR chi2 }(5)=10.97 \\
\text { Prob }>\text { chi } 2=0.05\end{array}$ \\
\hline Parameter & $n(\%)$ & OR $(95 \% \mathrm{CI})^{\mathrm{a}}$ & $P$ value \\
\hline Age & & $0.99(0.96-1.02)$ & 0.933 \\
\hline \multicolumn{4}{|l|}{ Gender } \\
\hline Male & $207(41)$ & $1.16(0.50-2.69)$ & 0.729 \\
\hline Female & $298(59)$ & 1.00 & \\
\hline \multicolumn{4}{|l|}{ Easy fatigue } \\
\hline Yes & $116(23)$ & $0.62(0.23-1.67)$ & 0.349 \\
\hline No & $389(77)$ & 1.00 & \\
\hline \multicolumn{4}{|l|}{ Smoking status } \\
\hline Smoker & $163(32.3)$ & $0.94(0.36-2.42)$ & 0.892 \\
\hline Nonsmoker & $342(67.7)$ & 1.00 & \\
\hline \multicolumn{4}{|l|}{ Exposure to DDS } \\
\hline Yes (study group) & $146(28.9)$ & $4.37(1.78-10.69)$ & 0.001 \\
\hline No (reference group) & $359(71.1)$ & 1.00 & \\
\hline
\end{tabular}

${ }^{\mathrm{a}} \mathrm{OR}$, odds ratio; $95 \%$ CI, $95 \%$ confidence interval.

\section{Results}

The general characteristics of the study populations are presented in Table 1 . The study group has an older population and a higher BMI than the reference one (56.1\% versus $42.3 \%$ of individuals with more than 41 years and $27.1 \mathrm{~kg} / \mathrm{m}^{2}$ versus $25.7 \mathrm{~kg} / \mathrm{m}^{2}$, resp.). On the other hand, the reference group has a higher percentage of smokers than the study group (37.6\% versus $19.1 \%)$.

Soil $\mathrm{CO}_{2}$ flux was significantly different $(P<0.001)$ between the studied areas (Table 1). According to criteria for diffuse degassing susceptibility areas defined by Viveiros et al. [14], all the analyzed buildings in Ponta Delgada are located in low susceptibility areas $\left(\mathrm{CO}_{2}\right.$ flux $\left.<25 \mathrm{~g} / \mathrm{m}^{2} / \mathrm{d}\right)$, while in Ribeira Quente 1.9\% of the buildings were located in moderate susceptibility areas (soil $\mathrm{CO}_{2}$ flux between $25 \mathrm{~g} / \mathrm{m}^{2} / \mathrm{d}$ and $50 \mathrm{~g} / \mathrm{m}^{2} / \mathrm{d}$ ) and the remaining $98.1 \%$ were in a high susceptibility area (soil $\mathrm{CO}_{2}$ flux $\geq 50 \mathrm{~g} / \mathrm{m}^{2} / \mathrm{d}$ ) (Supplementary Material 1 in Supplementary Material available online at http://dx.doi.org/10.1155/2015/326794).

3.1. Prevalence of Restrictive and Obstructive Respiratory Defects. The prevalence of restrictions in the study group was significantly higher than in the reference group $(10.2 \%$ versus $3.0 \%$, resp.; $P=0.001$ ). Similarly, the prevalence of COPD was significantly higher in the study group than in the reference one (33.6\% versus $11.9 \%$, resp.; $P<0.001$ ) (Figure 2). The prevalence of more severe obstructions was also higher in the study group compared to the reference one (mild, 15.7 versus 4.4 , moderate, 6.8 versus 2.2 , and severe, 4.7 versus 0 , resp.).

3.2. Restrictive or Obstructive Respiratory Defects and Exposure to Volcanogenic Air Pollution by DDS. Exposure to

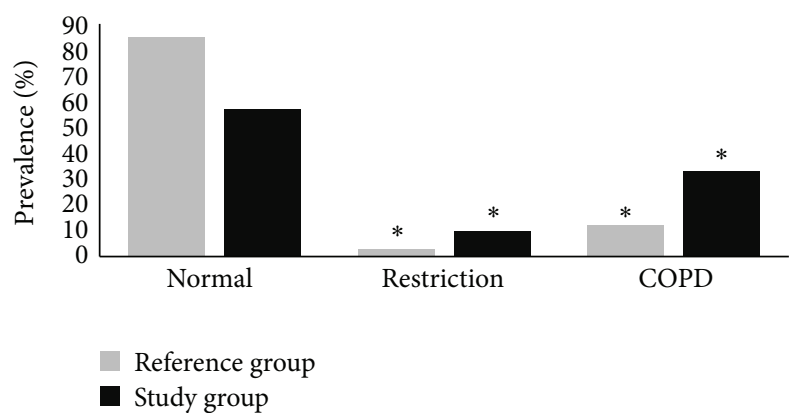

FIgURE 2: Proportion (\%) of individuals with obstructive and restrictive airway diseases in study (Ribeira Quente) and reference (Ponta Delgada) groups; ${ }^{*}$ significantly different at $P<0.05$.

volcanogenic air pollution by DDS was a significant predictor of the prevalence of respiratory restrictions and of COPD exacerbation in the multivariate analysis. After adjustment for age, gender, fatigue, and smoking status, a higher prevalence of respiratory restrictions was found associated with exposure to volcanogenic air pollution by $\mathrm{DDS}(\mathrm{OR}=4.4$; 95\% CI, 1.78-10.69; $P=0.001$ ) (Table 2). Also, after the adjustment for the same factors, a higher prevalence of respiratory obstructions was found associated with exposure to the volcanic environment $(\mathrm{OR}=2.8 ; 95 \% \mathrm{CI}, 1.60-4.99)$ (Table 3). Exacerbation in COPD severity was also found significantly associated with exposure to volcanogenic air pollution by DDS (OR = 3.2; 95\% CI, 1.82-5.58; $P<0.001)$ (Table 4).

The analyzed confounding factors did not show any significant association with respiratory restrictions (Table 2), but respiratory obstructions were significantly associated 
TABLE 3: Adjusted association between characteristics of study participants, exposure to volcanogenic soil diffuse degassing, and obstructive lung defects.

\begin{tabular}{|c|c|c|c|}
\hline Binomial logistic regression & & & $\begin{array}{l}\text { Number of obs. } 505 \\
\text { LR chi2 }(5)=60.80 \\
\text { Prob }>\text { chi } 2=<0.001\end{array}$ \\
\hline Parameter & $n(\%)$ & OR $(95 \% \mathrm{CI})^{\mathrm{a}}$ & $P$ value \\
\hline Age & & $1.04(1.02-1.06)$ & $<0.001$ \\
\hline \multicolumn{4}{|l|}{ Easy fatigue } \\
\hline Yes & $116(23)$ & $1.80(1.05-3.28)$ & 0.033 \\
\hline No & $389(77)$ & 1.00 & \\
\hline \multicolumn{4}{|l|}{ Gender } \\
\hline Male & $207(41)$ & $0.66(0.39-1.11)$ & 0.123 \\
\hline Female & $298(59)$ & 1.00 & \\
\hline \multicolumn{4}{|l|}{ Smoking status } \\
\hline Smoker & $163(32.3)$ & $2.34(1.35-4.06)$ & 0.002 \\
\hline Nonsmoker & $342(67.7)$ & 1.00 & \\
\hline \multicolumn{4}{|l|}{ Exposure to DDS } \\
\hline Yes (study group) & $146(28.9)$ & $2.83(1.60-4.99)$ & $<0.001$ \\
\hline No (reference group) & $359(71.1)$ & 1.00 & \\
\hline
\end{tabular}

${ }^{\mathrm{a}} \mathrm{OR}$, odds ratio; $95 \%$ CI, $95 \%$ confidence interval.

TABLE 4: Adjusted association between characteristics of study participants, exposure to volcanogenic soil diffuse degassing, and COPD exacerbation.

\begin{tabular}{|c|c|c|c|}
\hline Ordinal logistic regression & & & $\begin{array}{l}\text { Number of obs. } 505 \\
\text { LR chi2 } 2(5)=70.19 \\
\text { Prob }>\text { chi } 2=<0.001\end{array}$ \\
\hline Parameter & $n(\%)$ & OR $(95 \% \mathrm{CI})^{\mathrm{a}}$ & $P$ value \\
\hline Age & & $1.04(1.02-1.06)$ & $<0.001$ \\
\hline \multicolumn{4}{|l|}{ Easy fatigue } \\
\hline Yes & $116(23)$ & $1.80(1.00-3.24)$ & 0.046 \\
\hline No & $389(77)$ & 1.00 & \\
\hline \multicolumn{4}{|l|}{ Asthma } \\
\hline Yes & $43(8.5)$ & $2.25(1.05-4.82)$ & 0.037 \\
\hline No & $462(91.5)$ & 1.00 & \\
\hline \multicolumn{4}{|l|}{ Smoking status } \\
\hline Smoker & $163(32.3)$ & $2.11(1.25-3.56)$ & 0.005 \\
\hline Nonsmoker & $342(67.7)$ & 1.00 & \\
\hline \multicolumn{4}{|l|}{ Exposure to DDS } \\
\hline Yes (study group) & $146(28.9)$ & $3.19(1.82-5.58)$ & $<0.001$ \\
\hline No (reference group) & $359(71.1)$ & 1.00 & \\
\hline
\end{tabular}

${ }^{\mathrm{a}} \mathrm{OR}$, odds ratio; $95 \% \mathrm{CI}, 95 \%$ confidence interval.

with age, fatigue, and smoking status (Table 3). The increase in COPD severity was significantly associated with asthma and the abovementioned factors (Table 4).

\section{Discussion}

The association between exposure to air pollution and adverse respiratory effects has been widely demonstrated $[31,32]$. Such association is usually related to anthropogenic air pollution, while for volcanogenic pollution there are much fewer studies. Volcanoes and volcanic manifestations, such as fumaroles and hot and cold $\mathrm{CO}_{2}$-rich springs as well as degassing soils, release into the environment metals, hazardous aerosols, and gases that daily affect the quality of the environment and the health of human populations [33].

The measurements of $\mathrm{CO}_{2}$ flux revealed that the study group (from the hydrothermal area) is chronically exposed to elevated volcanogenic air pollution by soil diffuse degassing compared to the reference group (average values are $508 \mathrm{~g} /$ $\mathrm{m}^{2} / \mathrm{d} \quad(\approx 35.73 \mathrm{ppm} / \mathrm{s})$ versus $15.36 \mathrm{~g} / \mathrm{m}^{2} / \mathrm{d} \quad(\approx 1.08 \mathrm{ppm} / \mathrm{s})$, 
resp.). Carbon dioxide levels are described to be usually greater inside a building than outside $[34,35]$; therefore, these populations are much probably subjected to higher levels of indoor $\mathrm{CO}_{2}$ than the presented values. Also, independently of the biological $\mathrm{CO}_{2}$ contribution, the hydrothermal $\mathrm{CO}_{2}$ emission is permanent and thus the level of $\mathrm{CO}_{2}$ in the Ribeira Quente buildings must be always higher than the "normal" values and sporadically reach anomalous high values as recognized in previous works, only due to meteorological changes [13]. The threshold limit value for $8 \mathrm{~h}$ time weighted-average exposures to $\mathrm{CO}_{2}$ is $5000 \mathrm{ppm}$ (WHO), and possibly the average $\mathrm{CO}_{2}$ concentrations encountered in the buildings are below this limit and are not expected to cause health symptoms such as headaches, fatigue, and eye and throat irritation. However, the consequences of the permanent presence of indoor $\mathrm{CO}_{2}$ in concentrations higher than the outdoor environment are still far from being understood and may eventually lead to some stress effect in the organisms that needs to be better studied. In addition, the $\mathrm{CO}_{2}$ emission may be also associated with other volcanic emissions, as it is the case of the radioactive gas radon. The measurements performed showed that the study group is chronically exposed to elevated volcanogenic air pollution, namely, high $\mathrm{CO}_{2}$ soil diffuse degassing; high concentrations of $\mathrm{CO}_{2}$ can cause headaches due to hypercapnia and the decrease of $\mathrm{O}_{2}$ in the bloodstream [36]. When these two events combine, the body responds by increasing blood flow to the brain by dilating the blood vessels, resulting in pain [36]. A significant association was found between restrictive respiratory defects and the exposure to volcanogenic air pollution by DDS, measured as 4.4 times higher in the inhabitants of Ribeira Quente (study group), when compared to the reference one. A significant association was also found between obstructive respiratory defects and exposure to volcanogenic air pollution by DDS, measured as 2.8 times higher in the study group. None of the analyzed confounding factors (age, gender, fatigue, and smoking status) was significantly associated with respiratory restriction, but apart from gender all confounding factors were positively associated with respiratory obstructions.

Results also showed significant associations between the increase in the severity of COPD and the exposure to soil diffuse degassing in the study group when compared to the reference one, given as 3.2 times higher in Ribeira Quente inhabitants (study group). Age, asthma, fatigue, and smoking status were also significantly associated with the increase in COPD severity.

Age and smoking habits are well associated with COPD prevalence $[37,38]$. According to our results, the classification of subjects who are at risk is relevant in middle-aged and elderly persons (i.e., > 41 years old), individuals with asthma, and smokers. Aging affects the structure, function, and control of the respiratory system; according to Stanojevic et al. [39], both $\mathrm{FEV}_{1}$ and FVC decrease with age, and thus the observed increase in COPD associated with age was expected (since older individuals will have a reduced FVC and a reduced $\mathrm{FEV}_{1} / \mathrm{FVC}$ ratio). Also recently results from Eurostat [40] demonstrated that respiratory diseases such as bronchitis and asthma affect mainly older people, as almost
$90 \%$ of EU-28 deaths from these diseases occur among those aged 65 and above. Moreover, this report presents a standardized death rate from diseases of the respiratory system of at least 150 deaths per 100000 inhabitants; the highest death rates were observed in two Portuguese regions, the volcanic islands of Madeira (294.6 deaths per 100000 inhabitants) and Azores (195.8 deaths per 100000 inhabitants); the rest of the Portuguese territory (mainland) presented a death rate below 150 deaths per 100000 inhabitants; therefore, the observed results are in accordance with this general overview.

Regarding asthma, there might be a significant overlap with COPD, since both are characterized by an underlying airway inflammation, although the structural and pathophysiologic findings in both diseases can be usually differentiated [41]. According to the Global Initiative for Chronic Obstructive Lung Diseases [42], in individuals with chronic respiratory symptoms and fixed airflow limitation, it is difficult to differentiate asthma from COPD. However, there is epidemiological evidence that long-standing asthma can lead to fixed airflow limitation [43], which increases the frequency of asthma attacks [44].

Fatigue is considered the second most common symptom of COPD, after breathlessness [45]. The increased level of fatigue found in patients with COPD is associated with an increase in the severity of lung impairment and a reduction in exercise tolerance. Symptoms of fatigue can be physical and mental, such as lack of energy or poor concentration. Baghai-Ravary et al. [46] and Breslin et al. [47] found a relationship between fatigue and COPD, which persists at COPD exacerbations. Since COPD was observed mainly in elderly people that have diminished lung function and therefore a reduction in health status, fatigue was expected to be associated with COPD.

It is well established that tobacco is the most important causative factor for COPD, with individual susceptibility continuously interacting synergistically with other risk factors [48], such as age. According to Lundbäck et al. [49], lifelong smoking increases the chance of developing COPD and, thus, about $50 \%$ of the smokers eventually develop COPD during their lifetime. However, according to GOLD [42], other risk factors of COPD include exposure to air pollution, secondhand smoke and occupational dusts and chemicals, heredity, a history of childhood respiratory infections, and socioeconomic status. In the present study, air pollution by hydrothermal volcanism was proven to be a risk factor in COPD exacerbation.

It is well known that air pollution can perpetuate a chronic inflammatory process that potentially leads to lung diseases [31]. However, the majority of studies regard air pollutants of anthropogenic origin, such as $\mathrm{PM}_{10}, \mathrm{NO}_{2}, \mathrm{SO}_{2}$, and $\mathrm{O}_{3}[50,51]$, while only few studies were developed in areas with volcanic activity and associate volcanogenic pollutants with human airway diseases $[7,52]$. Longo and Yang [52] and Iwasawa et al. [8] reported a higher risk of acute bronchitis across the lifespan in humans exposed to sulfurous volcanic air pollution. Furthermore, in 2013, Camarinho et al. [22] showed that noneruptive active volcanism is associated with increased lung injury in mice. Thus, it is not unexpected to observe an increase in the exacerbation of 
COPD severity in the population living in Ribeira Quente, a volcanic area with elevated soil diffuse degassing. These findings also corroborate the study by Amaral and Rodrigues [19] that observed higher rates of chronic bronchitis in Furnas village inhabitants (in comparison to a reference group) and suggested that it could be partially associated with chronic exposure, in a very humid atmosphere, to environmental factors resulting from volcanic activity.

\section{Conclusions}

To our knowledge, this is the first study assessing long-term effects of $\mathrm{CO}_{2}$ emissions in hydrothermal areas on the development of respiratory defects. The results of this study show that long-term exposure to air pollution by soil diffuse degassing increases the risk of developing restrictive defects as well as the exacerbation of COPD in the inhabitants of hydrothermal volcanic areas. Therefore, mitigation measures should be implemented in populations inhabiting elevated diffuse degassing areas, such as the construction of natu$\mathrm{ral} /$ forced ventilation systems, as well as follow-up health programs in order to provide medical counseling when necessary. The results of the study also support the need to particularly follow up the asthmatic and the older individuals, since these factors are associated with exacerbation in COPD severity in individuals chronically exposed to volcanogenic soil diffuse degassing.

In addition, considering the positive trend of the $\mathrm{CO}_{2}$ in the atmosphere, areas as Ribeira Quente village can be used as natural analogous to studying the possible effects of these increases on the population.

\section{Conflict of Interests}

The authors declare that there is no conflict of interests.

\section{Acknowledgments}

The authors thank Catarina Silva, Ana Ferreira, Carolina Parelho, Carla Raposo, and Ricardo Camarinho for their support in field and laboratory work. Diana Linhares and Fátima Viveiros were supported, respectively, by Ph.D. and postdoc fellowships from the Fundo Regional da Ciência (Regional Government of the Azores) (PROEMPREGO Programme) (M3.1.2/F/019/2011 and M3.1.7/F/018/2011). The authors also thank the financial support of BioAir-Biomonitoring Air Pollution: Development of an Integrated System (M2.1.2/F/008/2011) from Fundo Regional da Ciência (Regional Government of the Azores).

\section{References}

[1] National Research Council, Active Tectonics: Impact on Society, The National Academies Press, Washington, DC, USA, 1986.

[2] K. B. Brunekreef, D. W. Dockery, and M. Krzyzanowski, "Epidemiologic studies on short-term effects of low levels of major ambient air pollution components," Environmental Health Perspectives, vol. 103, no. 2, pp. 3-13, 1995.
[3] J. McCreanor, P. Cullinan, M. J. Nieuwenhuijsen et al., "Respiratory effects of exposure to diesel traffic in persons with asthma," The New England Journal of Medicine, vol. 357, no. 23, pp. 23482358, 2007.

[4] S. Weichenthal, R. Kulka, A. Dubeau, C. Martin, D. Wang, and R. Dales, "Traffic-related air pollution and acute changes in heart rate variability and respiratory function in urban cyclists," Environmental Health Perspectives, vol.119, no. 10, pp.1373-1378, 2011.

[5] R. Dales, L. M. Kauri, S. Cakmak et al., "Acute changes in lung function associated with proximity to a steel plant: a randomized study," Environment International, vol. 55, pp. 15-19, 2013.

[6] B. Jacquemin, J. Lepeule, A. Boudier et al., "Impact of geocoding methods on associations between long-term exposure to urban air pollution and lung function," Environmental Health Perspectives, vol. 121, no. 9, pp. 1054-1060, 2013.

[7] G. Gudmundsson, "Respiratory health effects of volcanic ash with special reference to Iceland. A review," Clinical Respiratory Journal, vol. 5, no. 1, pp. 2-9, 2011.

[8] S. Iwasawa, Y. Kikuchi, Y. Nishiwaki et al., "Effects of $\mathrm{SO}_{2}$ on respiratory system of adult miyakejima resident 2 years after returning to the Island," Journal of Occupational Health, vol. 51, no. 1, pp. 38-47, 2009.

[9] B. M. Longo, W. Yang, J. B. Green, F. L. Crosby, and V. L. Crosby, "Acute health effects associated with exposure to volcanic air pollution (VOG) from increased activity at kilauea volcano in 2008," Journal of Toxicology and Environmental Health, Part A: Current Issues, vol. 73, no. 20, pp. 1370-1381, 2010.

[10] R. Searle, "Tectonic pattern of the Azores spreading centre and triple junction," Earth and Planetary Science Letters, vol. 51, no. 2, pp. 415-434, 1980.

[11] T. Ferreira, J. L. Gaspar, F. Viveiros, M. Marcos, C. Faria, and F. Sousa, "Monitoring of fumarole discharge and $\mathrm{CO}_{2}$ soil degassing in the Azores: contribution to volcanic surveillance and public health risk assessment," Annals of Geophysics, vol. 48, no. 4-5, pp. 787-796, 2005.

[12] J. E. Guest, J. L. Gaspar, P. D. Cole et al., "Volcanic geology of Furnas Volcano, Sao Miguel, Azores," Journal of Volcanology and Geothermal Research, vol. 92, no. 1-2, pp. 1-29, 1999.

[13] F. Viveiros, T. Ferreira, C. Silva, and J. L. Gaspar, "Meteorological factors controlling soil gases and indoor $\mathrm{CO}_{2}$ concentration: a permanent risk in degassing areas," Science of the Total Environment, vol. 407, no. 4, pp. 1362-1372, 2009.

[14] F. Viveiros, C. Cardellini, T. Ferreira, S. Caliro, G. Chiodini, and C. Silva, "Soil $\mathrm{CO}_{2}$ emissions at Furnas volcano, São Miguel Island, Azores archipelago: volcano monitoring perspectives, geomorphologic studies, and land use planning application," Journal of Geophysical Research B: Solid Earth, vol. 115, no. 12, Article ID B12208, 2010.

[15] M. Durand, "Indoor air pollution caused by geothermal gases," Building and Environment, vol. 41, no. 11, pp. 1607-1610, 2006.

[16] Y. Y. You, C. Niu, J. Zhou et al., "Measurement of air exchange rates in different indoor environments using continuous $\mathrm{CO}_{2}$ sensors," Journal of Environmental Sciences, vol. 24, no. 4, pp. 657-664, 2012.

[17] World Health Organization, Programmes and Projects: Indoor Air Pollution, WHO, 2008.

[18] J. Balmes, M. Becklake, P. Blanc et al., "American Thoracic Society Statement: occupational contribution to the burden of airway disease," American Journal of Respiratory and Critical Care Medicine, vol. 167, no. 5, pp. 787-797, 2003. 
[19] A. F. S. Amaral and A. S. Rodrigues, "Chronic exposure to volcanic environments and chronic bronchitis incidence in the Azores, Portugal," Environmental Research, vol. 103, no. 3, pp. 419-423, 2007.

[20] A. Amaral, V. Rodrigues, J. Oliveira et al., "Chronic exposure to volcanic environments and cancer incidence in the Azores, Portugal," Science of the Total Environment, vol. 367, no. 1, pp. 123-128, 2006.

[21] A. S. Rodrigues, M. S. C. Arruda, and P. V. Garcia, "Evidence of DNA damage in humans inhabiting a volcanically active environment: a useful tool for biomonitoring," Environment International, vol. 49, pp. 51-56, 2012.

[22] R. Camarinho, P. V. Garcia, and A. S. Rodrigues, "Chronic exposure to volcanogenic air pollution as cause of lung injury," Environmental Pollution C, vol. 181, pp. 24-30, 2013.

[23] B. G. Ferris, "Epidemiology standardization project II," The American Review of Respiratory Disease, vol. 118, no. 6, pp. 753, 1978.

[24] British Medical Research Council Committee on the Aetiology of Chronic Bronchitis, "Standardized questionnaire on respiratory symptoms," British Medical Journal, no. 2, p. 1965, 1960.

[25] Instituto Nacional de Estatística, Censos, INE, 2011, http://censos.ine.pt.

[26] F. Viveiros, C. Cardellini, T. Ferreira, and C. Silva, "Contribution of $\mathrm{CO}_{2}$ emitted to the atmosphere by diffuse degassing from volcanoes: the furnas volcano case study," International Journal of Global Warming, vol. 4, no. 3-4, pp. 287-304, 2012.

[27] M. R. Miller, J. Hankinson, V. Brusasco et al., "Standardisation of spirometry," European Respiratory Journal, vol. 26, no. 2, pp. 319-338, 2005.

[28] American Thoracic Society, "Standardization of spirometry, 1994 update," American Journal of Respiratory and Critical Care Medicine, vol. 152, no. 3, pp. 1107-1136, 1995.

[29] G. Chiodini, R. Cioni, M. Guidi, B. Raco, and L. Marini, "Soil $\mathrm{CO}_{2}$ flux measurements in volcanic and geothermal areas," Applied Geochemistry, vol. 13, no. 5, pp. 543-552, 1998.

[30] IBM SPSS 20.0, IBM SPSS Statistics 20 Core System User's Guide, USA, 2011.

[31] T. Götschi, J. Heinrich, J. Sunyer, and N. Künzli, "Long-term effects of ambient air pollution on lung function: a review," Epidemiology, vol. 19, no. 5, pp. 690-701, 2008.

[32] G. Weinmayr, E. Romeo, M. de Sario, S. K. Weiland, and F. Forastiere, "Short-Term effects of $\mathrm{PM}_{10}$ and $\mathrm{NO}_{2}$ on respiratory health among children with asthma or asthma-like symptoms: a systematic review and Meta-Analysis," Environmental Health Perspectives, vol. 118, no. 4, pp. 449-457, 2010.

[33] A. Amaral and A. Rodrigues, "Volcanogenic contaminants: chronic exposure," in Encyclopedia of Environmental Health, J. Nriagu, S. Kacwe, T. Kawamoto, J. A. Patz, and D. M. Rennie, Eds., vol. 5, pp. 645-653, Elsevier, 2011.

[34] H. H. Denli, D. Z. Seker, and S. Kaya, "GIS based carbon dioxide concentration research in ITU campus, Istanbul-Turkey," in Proceedings of the FIG Congress Engaging the ChallengesEnhancing the Relevance, Kuala Lumpur, Malaysia, June 2014.

[35] D. H. Mudarri, "Potential correlation factors for interpreting $\mathrm{CO}_{2}$ measurements in buildings," ASHRAE Transactions, vol. 103, no. 2, pp. 244-255, 1997.

[36] S. A. Rice, "Human health risk assessment of $\mathrm{CO}_{2}$ : survivors of acute high-level exposure and populations sensitive to prolonged low-level exposure," in Proceedings of the 3rd Annual Conference on Carbon Sequestration Rice, Alexandria, Va, USA, May 2004.
[37] P. Lange, "Chronic care for COPD patients in Denmark," Pneumonologia i Alergologia Polska, vol. 80, no. 4, pp. 292-295, 2012.

[38] A. Lindberg, B. Eriksson, L.-G. Larsson, E. Rönmark, T. Sandström, and B. Lundbäck, "Seven-year cumulative incidence of COPD in an age-stratified general population sample," Chest, vol. 129, no. 4, pp. 879-885, 2006.

[39] S. Stanojevic, A. Wade, J. Stocks et al., "Reference ranges for spirometry across all ages: a new approach," The American Journal of Respiratory and Critical Care Medicine, vol. 177, no. 3, pp. 253-260, 2008.

[40] Eurostat, Regional Yearbook. General and Regional Statistics: Statistical Books, Publications Office of the European Union, Luxembourg, Luxembourg, 2014.

[41] T. Welte and D. A. Groneberg, "Asthma and COPD," Experimental and Toxicologic Pathology, vol. 57, no. 2, pp. 35-40, 2006.

[42] Global Initiative for Chronic Obstructive Lung Diseases (GOLD), Global Strategy for Diagnosis, Management, and Prevention of Chronic Obstructive Pulmonary Disease, GOLD, 2010, http://www.goldcop.com.

[43] P. Lange, J. Parner, J. Vestbo, P. Schnohr, and G. Jensen, "A 15-year follow-up study of ventilatory function in adults with asthma," The New England Journal of Medicine, vol. 339, no. 17, pp. 1194-200, 1998.

[44] K.-H. Kim, S. A. Jahan, and E. Kabir, "A review on human health perspective of air pollution with respect to allergies and asthma," Environment International, vol. 59, pp. 41-52, 2013.

[45] J. S. Paddison, T. W. Effing, S. Quinn, and P. A. Frith, "Fatigue in COPD: association with functional status and hospitalisations," European Respiratory Journal, vol. 41, no. 3, pp. 565-570, 2013.

[46] R. Baghai-Ravary, J. K. Quint, J. J. P. Goldring, J. R. Hurst, G. C. Donaldson, and J. A. Wedzicha, "Determinants and impact of fatigue in patients with chronic obstructive pulmonary disease," Respiratory Medicine, vol. 103, no. 2, pp. 216-223, 2009.

[47] E. Breslin, C. P. van der Schans, S. Breukink et al., "Perception of fatigue and quality of life in patients with COPD," Chest, vol. 114, no. 4, pp. 958-964, 1998.

[48] S. Marsh, S. Aldington, P. Shirtchiffe, M. Weatherall, and R. Beasley, "Smoking and COPD: what really are the risks?" European Respiratory Journal, vol. 28, no. 4, pp. 883-884, 2006.

[49] B. Lundbäck, A. Lindberg, M. Lindström et al., "Not 15 but $50 \%$ of smokers develop COPD? - report from the obstructive lung disease in Northern Sweden studies," Respiratory Medicine, vol. 97, no. 2, pp. 115-122, 2003.

[50] M. Kampa and E. Castanas, "Human health effects of air pollution," Environmental Pollution, vol. 151, no. 2, pp. 362-367, 2008.

[51] W. MacNee and K. Donaldson, "Mechanism of lung injury caused by PM10 and ultrafine particles with special reference to COPD," European Respiratory Journal, vol. 21, supplement 40, pp. 47s-51s, 2003.

[52] B. M. Longo and W. Yang, "Acute bronchitis and volcanic air pollution: a community-based cohort study at Kilauea Volcano, Hawai'i, USA," Journal of Toxicology and Environmental Health, Part A: Current Issues, vol. 71, no. 24, pp. 1565-1571, 2008. 

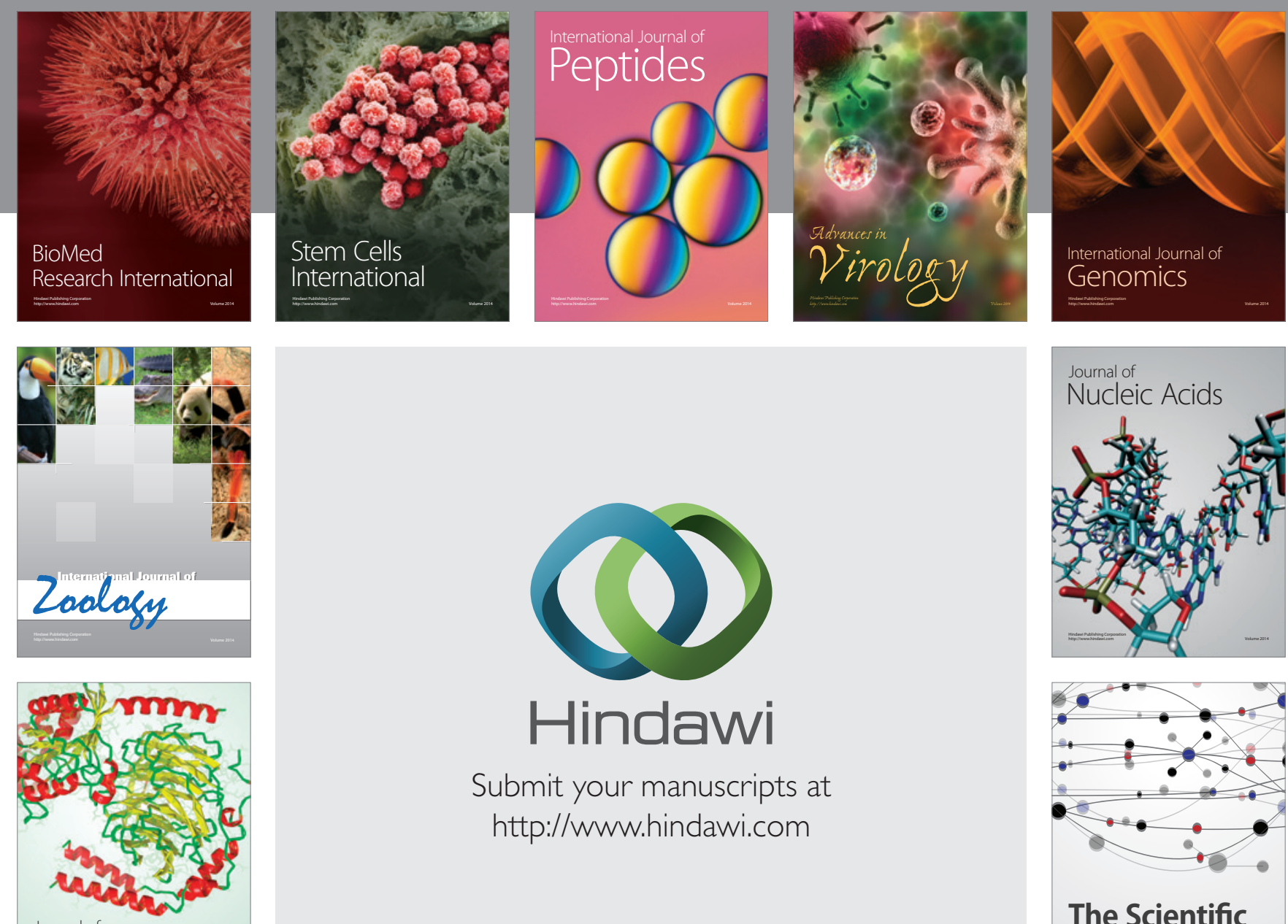

Submit your manuscripts at

http://www.hindawi.com

Journal of
Signal Transduction
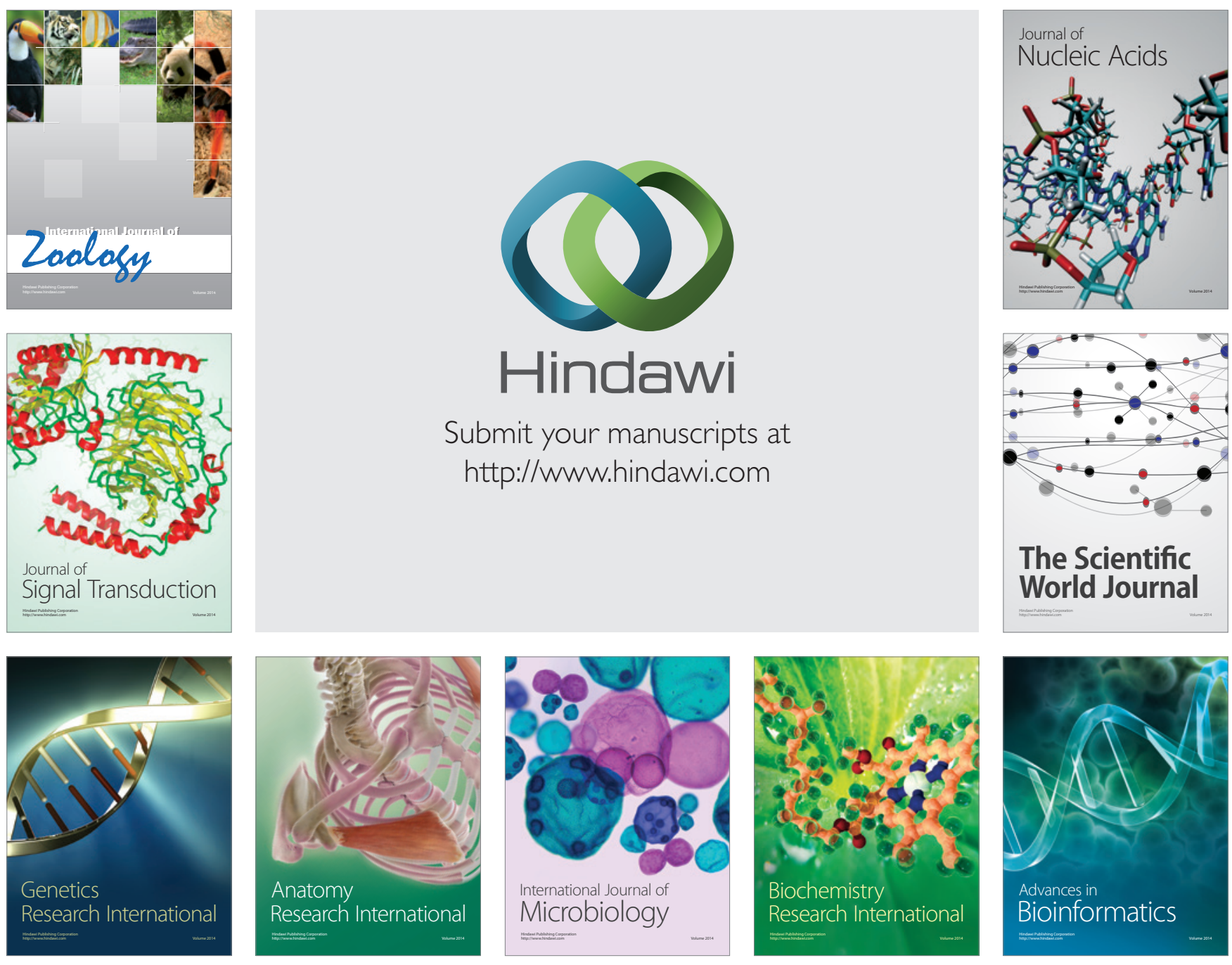

The Scientific World Journal
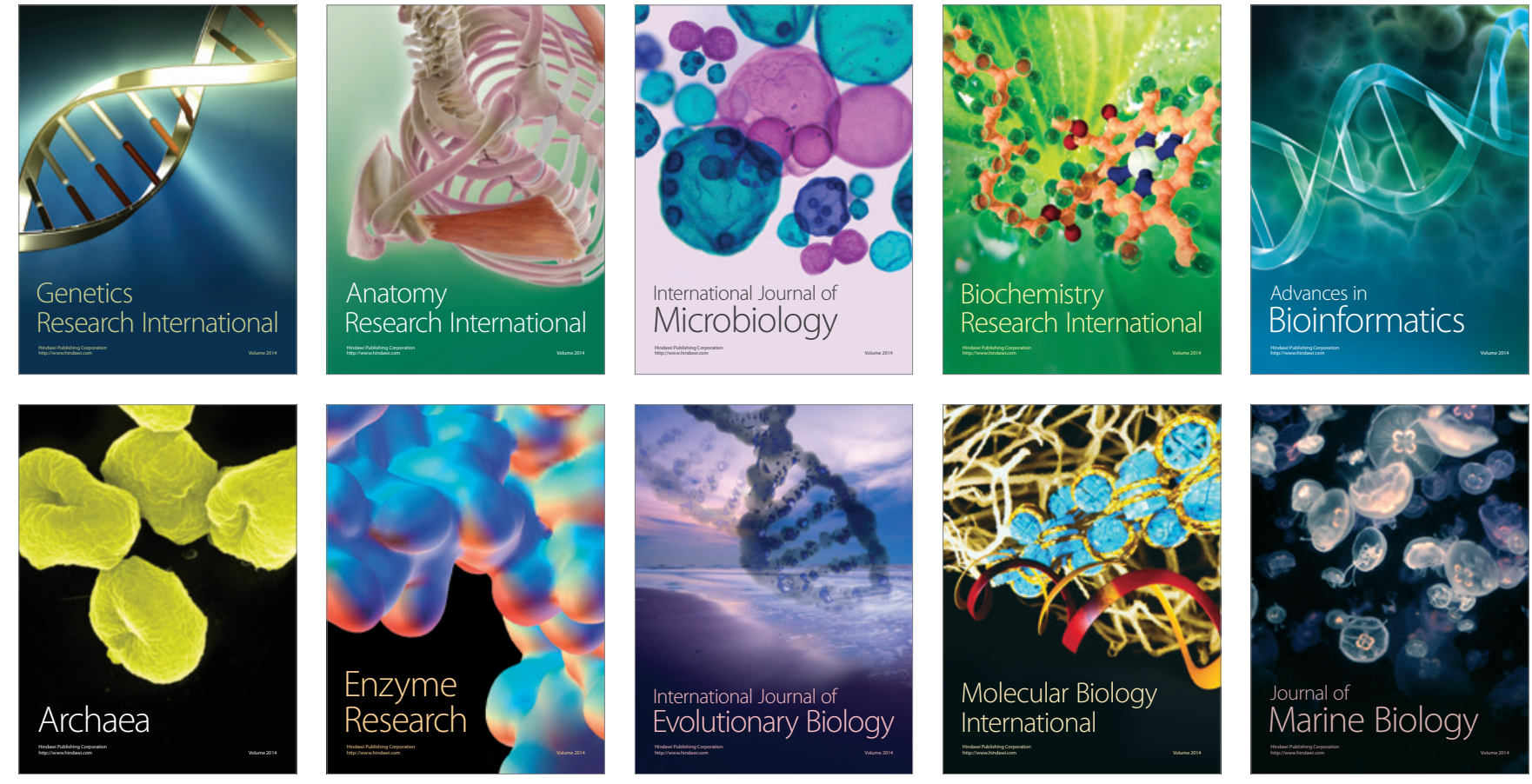